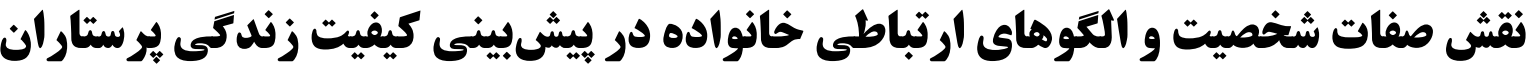

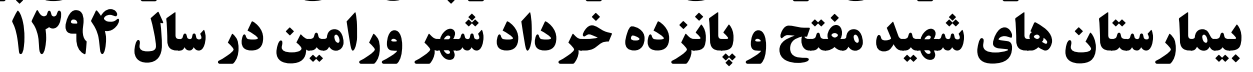

مهشيد مجتهدى'، جمال عاشورى "*r"

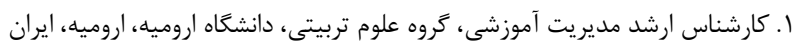

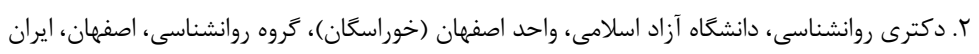

\section{Olus}

مقدمه: كيفيت زندگى تحت تاثير عوامل روانشناختى زيادى است كه از مهمترين آنها مىتوان به صفات

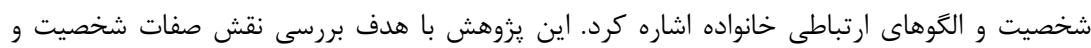

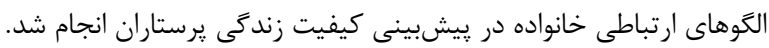

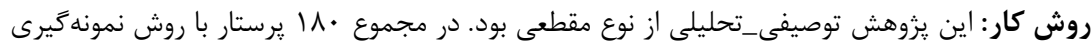

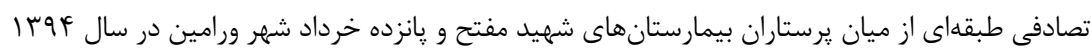

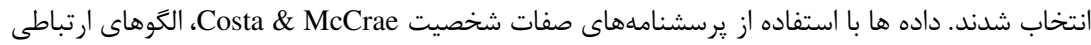

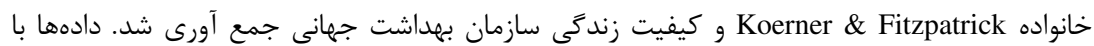

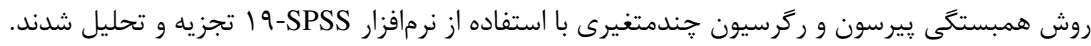

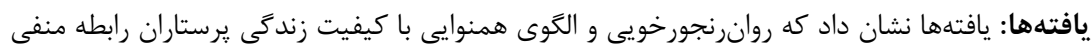

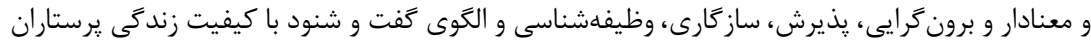

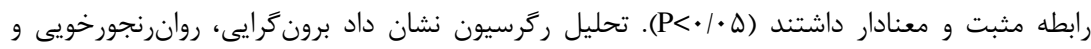

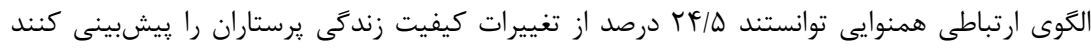

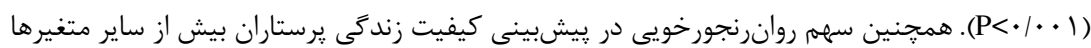
بود (P< ( نتيجه كيرى: برونَرايى، روانرنجورخويى و الكوى ارتباطى همنوايى توانايى ييشبينى معنادار كيفيت

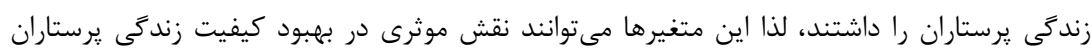

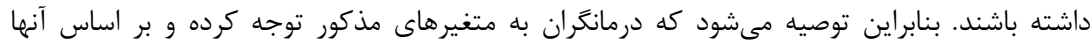

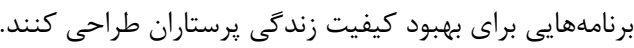

\section{مشخصات مقالد}

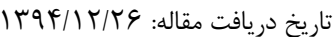

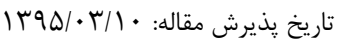

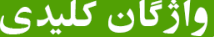

صفات شخصيت الكوهاى ارتباطى خانواده كيفيت زندى

يرستاران

\section{فويسنله مسنول}

جمال عاشورى،دكترى روانشناسى، دانشكاه آزاد اسلامى، واحد اصفهان (خوراسكان)،

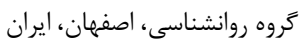

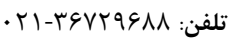
ايميل: Jamal_ashoori@Yahoo.com

تمامسى حقـوق نشــر بــراى دانشــاه

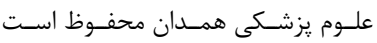

يكى از آشكارترين مسائلى كه در هر سازمانى به ويزه بيمارستان استرس مىشوند شامل فشار زياد كار، كار در شيفتهاى شبانه، ذهن كادر اجرايى را مشغول مىسازد، مساله كيفيت زندگى تقاضاهاى زياد در محل كار، سختى كار، مواجهه با اورزانس

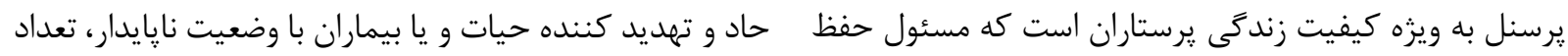

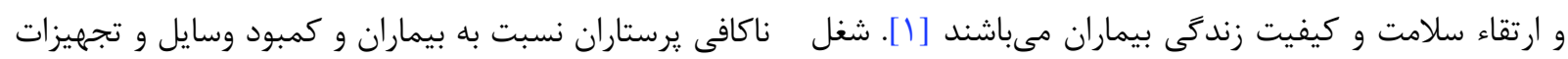

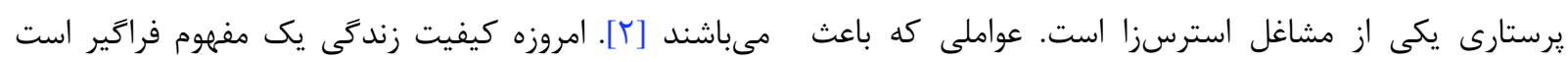


از رابطه مولفههاى شخصيتى با كيفيت زندكى است [1-11]. براى مثال Takeshita و همكاران (ها • (T) ضمن يزوهشى درباره ارتباط صفات شخصيت با كيفيت زندگى به اين نتيجه رسيدند كه روانرنجورخويى با كيفيت زندگى رابطه معنادار معكوس باسي و برونگرايى، سازگارى و وظيفهشناسى با كيفيت زندكى رابطه معنادار مستقيم داشت [1]]. همجنين شيخالاسلامى و

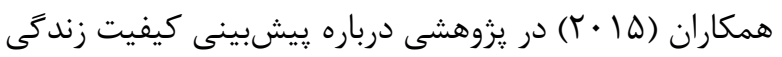

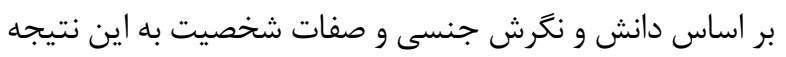
رسيدند كه روانرنجورخويى با كيفيت زندكى رابطه منفى و معنادار و برون دانش و نكَرش جنسى با كيفيت زندگى رابطه مثبت و معنادار داشت [• [1]. يكى ديخر از عوامل روانشناختى مرتبط با كيفيت زندگى، الكوهاى ارتباطى خانواده مىباشد. كيفيت زندگى افراد تحت تاثير محيطها و روابط اجتماعى قرار دارد و از آنجا كه خانواده اولين نظامى است كه كودك در آن جشم باز مى كند،

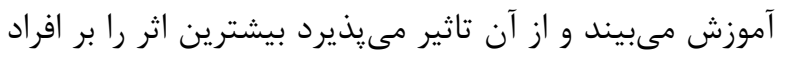

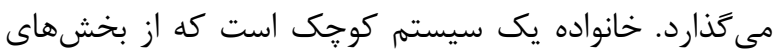

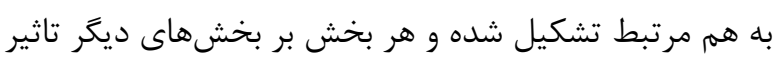

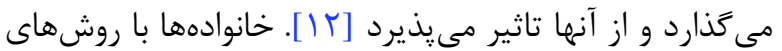
تربيتى و تعاملهاى متفاوت بر زندگى آينده فرزندان خود تاثير بسيارى دارند. زيرا فرزندان بيشتر وقت خود را در خانه سيرى مى كنند و به دليل ارتباطات ميان اعضاى خانواده از يكديكر تاثير مىيذيرند. بنابراين امروزه به نقش خانواده در شكل گيرى

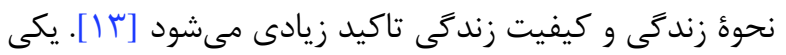
از مدلهاى مطرح در خانواده كه به تعاملات در خانواده و نقش

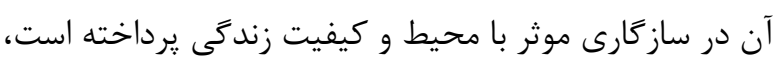

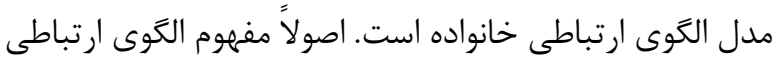

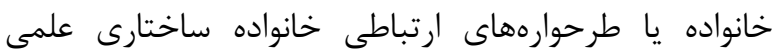

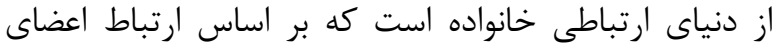

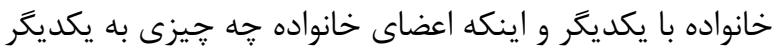
مى گويند و جه كارى انجام مىدهند و اينكه جه معنايى از

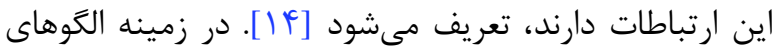

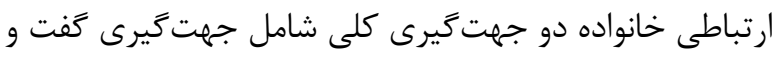
شنود و جهت كيرى همنوايى وجود دارد. منظور از جهت گيرى
كه از سلامت فيزيكى، رشد شخصى، حالات روانشناختى، سطح استقلال، روابط اجتماعى و روابط با نهادهاى برجسته محيط تاثير مىيذيرد و بر ادراك فرد مبتنى است. در واقع كيفيت زندگى گسترهاى شامل ابعاد عينى و ذهنى است كه در تعامل با يكديكر مىباشند [س]]. كيفيت زندگى يك سازه

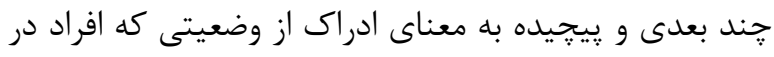

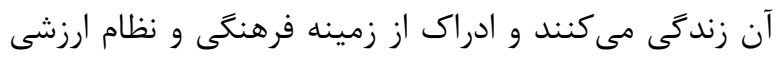
كه در آن قرار دارند، مى باشد كه اين ادراك بر اساس اهداف، آنداف

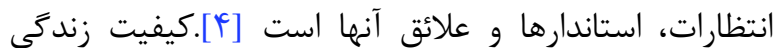
تحت تاثير عوامل روانشناختى زيادى است كه از مهمترين آنها مىتوان به صفات شخصيت و الكوهاى ارتباط خانواده اشاره كرد. يكى از عوامل روانشناختى مرتبط با كيفيت زندگى، صفات شخصيت مىباشد. شخصيت مجموعه سازمان يافته و واحدى متشكل از خصوصيات نسبتا ثابت و با دوام است كه مهات

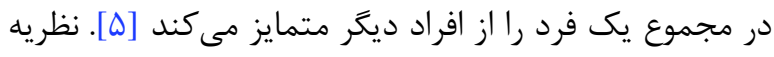
هاى شخصيت با استفاده از ديدكاههاى صفت و ديدكاههاى

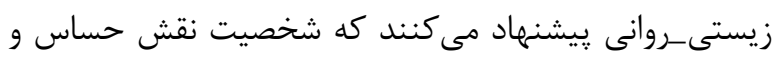

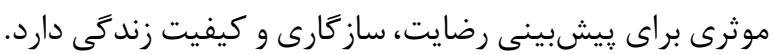
زيرا شخصيت يك عامل مهمم و موثر در برقرارى سطح تعادل بهنجار مىباشد [9]. بر اساس نظر Costa \& McCrae (r (199) شخصيت، صفات شخصيت داراى ينج مولفه روانرنجورخويى (Extroversion)، (Neuroticism) ، بذيرش (Openness)، سازكارى (Agreeableness) و وظيفهشناسى (Conscientiousness) مىباشد. روانرنجورخويى به تمايل فرد براى تجربه اضطراب،

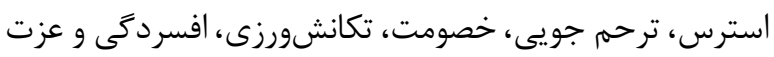
نفس קايين اشاره دارد، در حالى كه برون كرايى به تمايل فرد

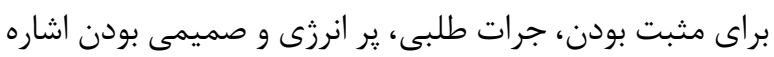
مى كند. يذيرش به تمايل فرد براى كنجكاوى، عشق به هنر، هنرمندى، انعطاف يذيرى و خردورزى اشاره دارد، در حالى لى كه سازگارى تمايل فرد را براى بخشندكى، مهربانى، سخاوت، همدلى، همفكرى، نوع دوستى و اعتمادورزى مد نظر قرار مى دهد. سرانجام اينكه وظيفهشناسى به تمايل فرد براى منظهم بودن، كار ا بودن، قابليت اعتماد و اتكا، خودنظم بخشى، يِيشرفت

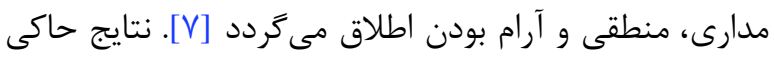


همنوايى ميزان فشارى است كه خانواده بر اعضا، براى همرأيى يزوهش همه يرستاران بيمارستانهاى شهيد مفتح و پانزده

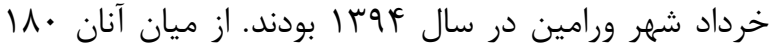
يرستار به صورت تصادفى طبقهاى انتخاب شدند. براى انتخاب اعضاى نمونه پِ از مشخص شدن ليست يرستاران هر دو بيمارستان، به نسبت حجم يرستاران هر بيمارستان، به همان

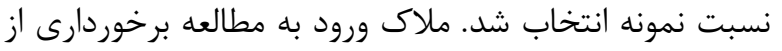
سلامت جسمانى و روانى و عدم عامل رخداد استرسزا مانند طلاق يا مرك عزيزان نزديك در شش ماه كذشته بود. همجنين

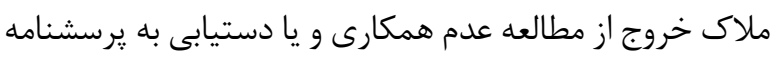

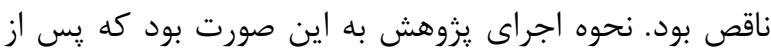

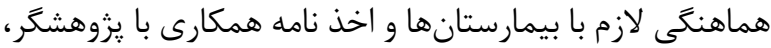
هدف يزوهش و رعايت اصل رازدارى براى افراد نمونه توضيح داده شد. سيس از آنان خواسته شد تا رضايتنامه كتبى شركت در يزوهش را امضا كنند و با دقت به يرسشنامهاى زير را ياسخ دهند. يرسشنامه صفات شخصيت Personality (1994) Costa \& McCrae توسط (Traits Questionnaire

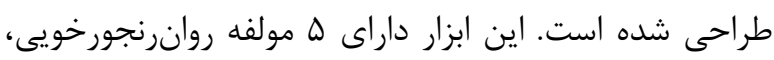

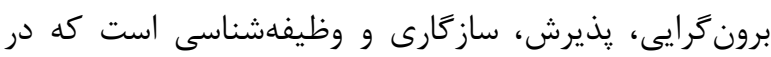

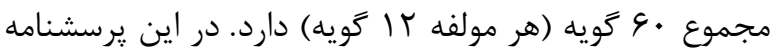
باسخ هر كويه با استفاده از مقياس ينج درجهاى ليكرت از يك تا ينج نمرهزذارى مىشود و نمره مولفه ها با جمع كردن نمره

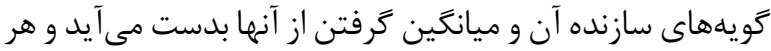
جه نمره آزمودني در يك مولفه بيشتر باشد به ميزان بيشتري

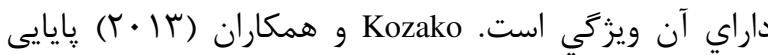
مولفههاى روانرنجورخويى، برون آيى، يذيرش، سازگًارى و

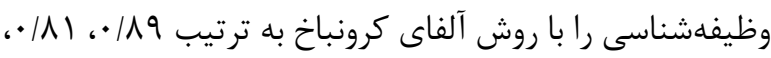

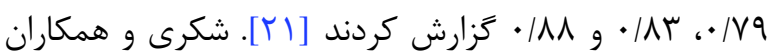

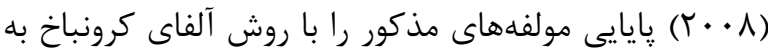

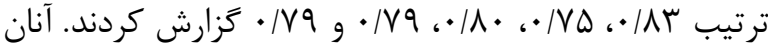
روايى يرسشنامه را با روش تحليل عاملى محاسبه و گزارش كردند كه هر ينج عامل برازش قابل قبولى داشت [rT]]. در اين مطالعه ضرايب يايايى مولفههاى مذكور با روش آلفاى كرونباخ

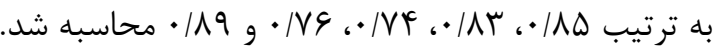
و يكسانسازى كرايشها، ارزشها و باورها وارد مى آورد. در اين الكو ارتباط ميان نسلها بر حرف شنوى از يدر و مادر و ديكر بزركسالان استوار است. جهت گيرى گفت و شنود به فضايى اشاره دارد كه اعضاى خانواده به تعاملات خودانگيخته با يكديكر

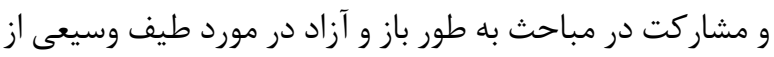
موضوعات و ابراز ايدههاى جديد تشويق مىشوند [ه I]. نتايج يزوهشها حاكى از رابطه الكوهاى ارتباطى خانواده با كيفيت

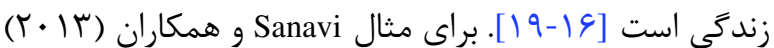
ضمن بررسى الكوهاى ارتباطى خانواده و سبكهاى والدينى با كيفيت زندگى به اين نتيجه رسيدند كه الكوى ارتباطى كفت و شنود با كيفيت زندگى رابطه معنادار مثبت داشت، اما الكَوى ارتباطى همنوايى با كيفيت زندكى رابطه معنادارى

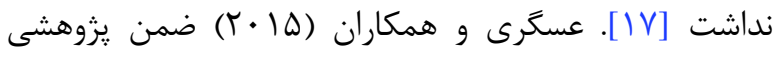
درباره رابطه الكوهاى ارتباطى خانواده و تمايز يافتكى خود با كيفيت زندگى به اين نتيجه رسيدند كه الكوى ارتباطى كَفت و شنود و تمايز يافتكى خود با كيفيت زندكى رابطه معندادار

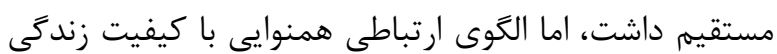
رابطه معنادارى نداشت [1/]]. با توجه به اينكه بيماران اغلب

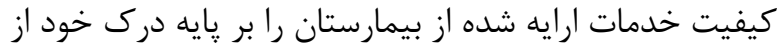
مراقبت يرستارى بنا مى كنند و جون خدمات يرستارى نقش بسيار مهمى در رضايت بيماران دارد، مىتوان انتظار داشت كه ويزگى هاى روانشناختى يرستاران بر رضايت بيماران تاثيركذار

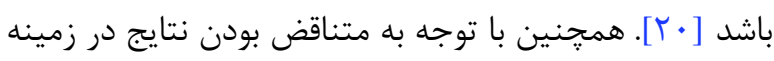

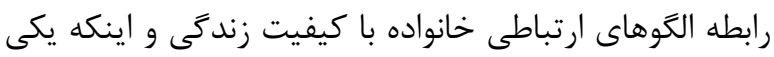

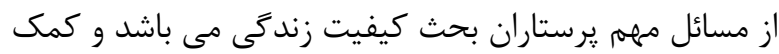
به اين افراد براى بهبود وضعيت زندكى امرى ضرورى و اجتناب نايذير است، لذا براى اين منظور بايد به بررسى جنبه هاى

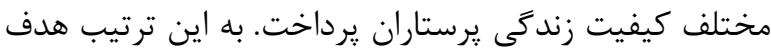
كلى اين يزوهش بررسى نقش صفات شخصيت و الكوهاى ارتباطى خانواده در پِيشبينى كيفيت زندگى يرستاران بود.

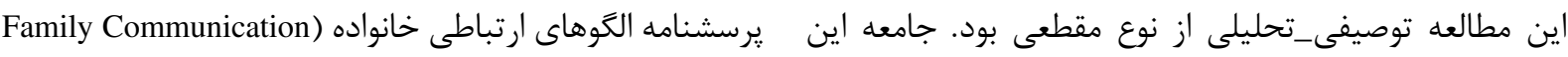


Koerner \& Fitzpatrick توسط (Patterns Questionnaire

شركتكنندًان اين يزوهش •11 يرستار با ميانكين سنى

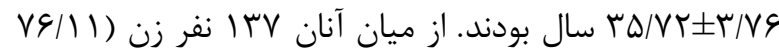

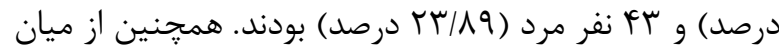

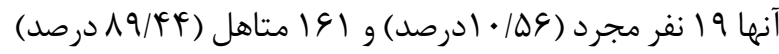

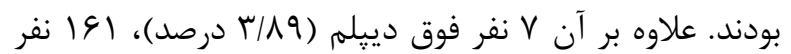

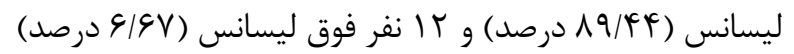
بودند. در جدول ا براى بررسى روابط ميان متغيرها ميانخين،

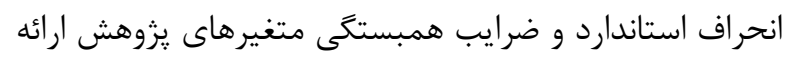

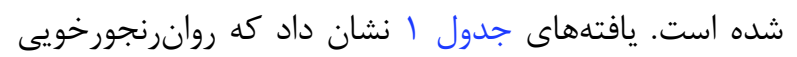

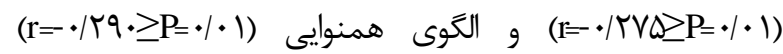
با كيفيت زندگى رابطه منفى و معنادار و برونگرايى

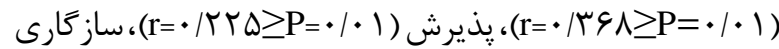

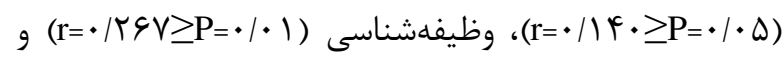

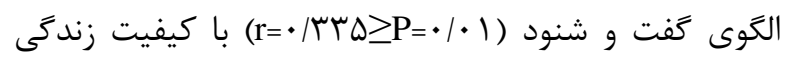
رابطه مثبت و معنادار داشتند. رابطه ساير متغيرها با يكديكر

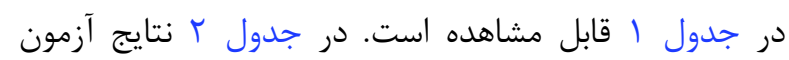

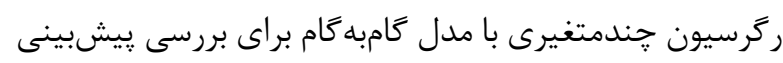

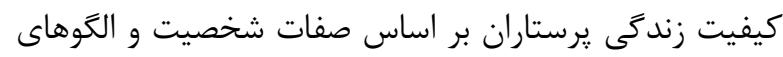
ارتباطى خانواده ارائه شده است. يافتههاى جدول بر بن نشان داد

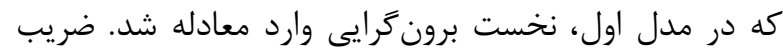

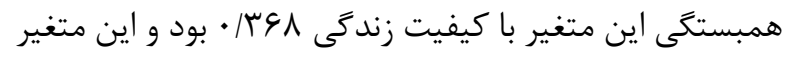

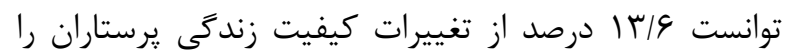

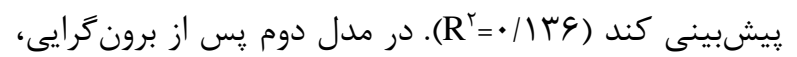

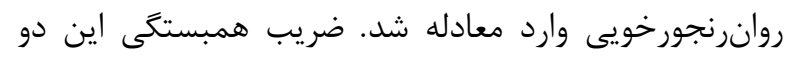

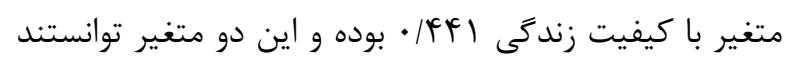

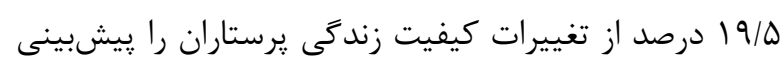

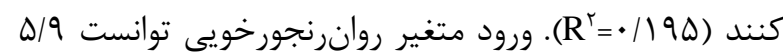

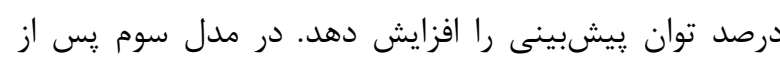
برون كرايى و روانرنجورخويى، الكوى همنوايى وارد معادله شد.

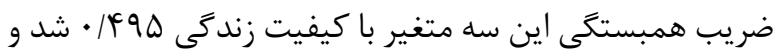
اين سه متغير توانستند ه/ أ درصد از تغييرات كيفيت زندكى

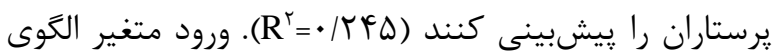

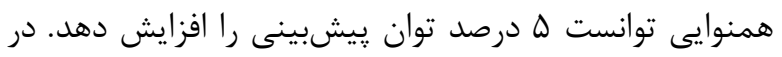

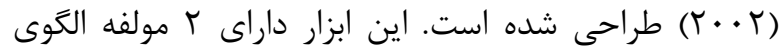
ارتباطى كفت و شنود و الكوى ارتباطى همنوايى است كه

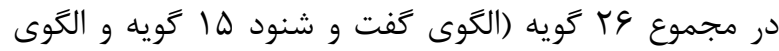

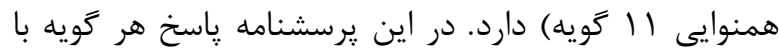

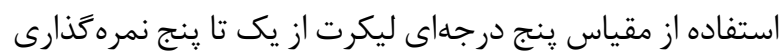

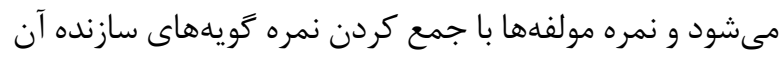

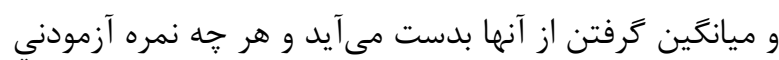

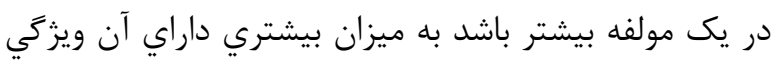

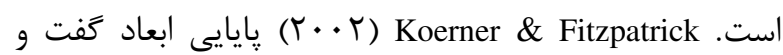
شنود و همنوايى را با روش آلفاى كرونباخ به ترتيب 91/. و 9T/ • تزارش كردند [4 [1]. همجنين كورش نيا و همكاران

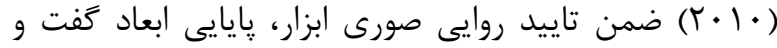
شنود و همنوايى را با روش آلفاى كرونباخ به ترتيب AV/ • و و

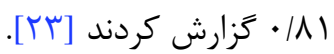

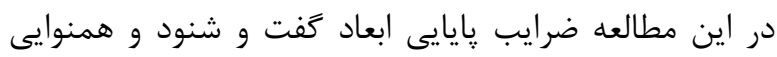

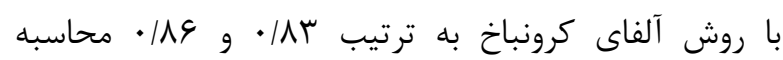
شد.يرسشنامه كيفيت زندكى (Life Quality Questionnaire) توسط World Health Organization است. اين ابزار داراى צץ گويه است كه با استفاده از مقياس ينج درجهاى ليكرت از يك تا ينج نمرهذارى مى آنود و نمره

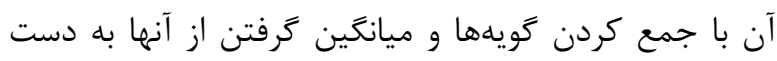

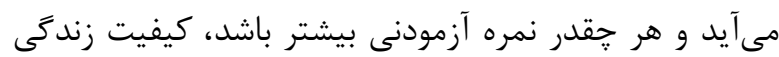

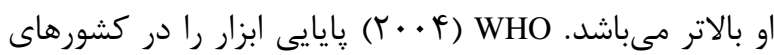

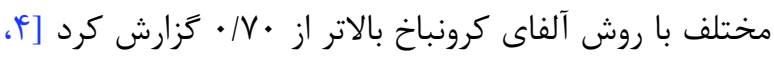

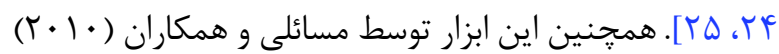

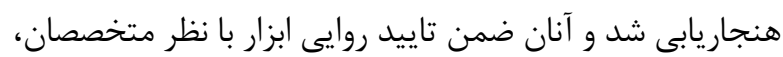

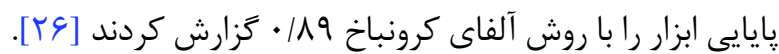

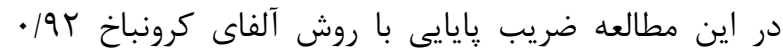
محاسبه شد. همجنين براى تحليل دادهها در سطح توصيفى از شاخص هاى توصيفى و در سطح استنباطى از روش همبستكى

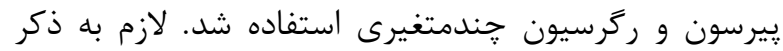
است كه براى تحليل دادهها از نرمافزار

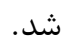




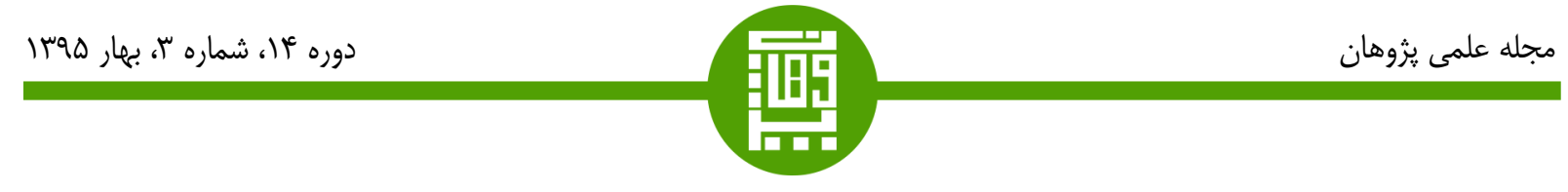

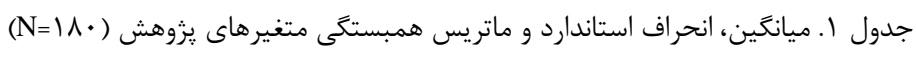

\begin{tabular}{|c|c|c|c|c|c|c|c|c|c|c|}
\hline$\wedge$ & $v$ & 9 & $\Delta$ & F & $r$ & $r$ & 1 & انحراف معيار & ميانگين & متغيرها \\
\hline & & & & & & & 1 & $\cdot 10 \cdot r$ & $r / \cdot V r$ & ا. روانر نجورخويى \\
\hline & & & & & & 1 & $\cdot 1 \cdot 19$ & $\cdot 10 \cdot 9$ & $r / \mathcal{\Psi} \wedge$. & r. برونَرايى \\
\hline & & & & & 1 & $* * \cdot / 49 \Delta$ & $\cdot 1 \cdot \sqrt{ } 9$ & •/ & r/rqV & r. . يذيرش \\
\hline & & & & 1 & .1 .94 & $* \cdot / 10$ & $* *_{-} \cdot / 4 \cdot 9$ & . IFTI & ( & F. سازَارى \\
\hline & & & 1 & $* * \cdot / \Delta \Delta$ & $* * / 4 \wedge \varphi$ & $* * \cdot / \Delta F T$ & $*_{*} \cdot \cdot / r \mid f$ & .109. & r/ब9r & ه. وظيفهشناسى \\
\hline & & 1 & $* * / \mathcal{Y} \wedge r$ & .1 .94 & $* * \cdot / 4 \& \mu$ & $* * / 4 \wedge 19$ & $.1 \cdot 9 \Delta$ & . /DTq & r/DG & و. كفت و شنود \\
\hline & 1 & $\cdot 1 \cdot \lambda r$ & $\cdot / \cdot Y \Lambda$ & $*_{-} \cdot / / V \Delta$ & $* \cdot / / \Delta \Lambda$ & $* * \cdot / T Y V$ & $* * \cdot / r \cdot r$ & $\cdot /$ Fr & $r / .91$ & V. همنوايى \\
\hline 1 & $* *_{-} \cdot / r q$. & ***/rra & $* * / r \& V$ & $* . / 1 \mathrm{~F}$. & $* * \cdot / Y T \Delta$ & $* * /$ r $4 \Lambda$ & $* *_{-} \cdot / T V D$ & - IFED & T/TFD & ^. كيفيت زندكى \\
\hline
\end{tabular}

$* * \mathrm{P} \leq \cdot / \cdot 1 \quad * \mathrm{P} \leq \cdot / \cdot \Delta$

جدول r. نتايج تحليل ركرسيون جندمتغيرى با مدل گام بهَام براى بيشبينى كيفيت زندگى

\begin{tabular}{|c|c|c|c|c|c|c|c|c|}
\hline 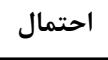 & df $\mathrm{T}$ & df) & 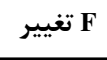 & R & Rr & $\mathbf{R}$ & متغير پيشبين & 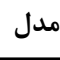 \\
\hline$\cdot 1 \cdot \cdots 1$ & $I V \wedge$ & 1 & $r V / 91 \wedge$ &.$/ 1 \% 4$ &.$/ 1{ }^{\prime}$ & $\cdot / 49 \wedge$ & برون & 1 \\
\hline$\cdot 1 \cdot \cdot 1$ & IVV & 1 & $\mid r / \cdot F r$ & $\cdot 1 \cdot \Delta q$ &.$/ 190$ & $\cdot|f| \psi \mid$ & برون كرايى و روانرنجورخويى & r \\
\hline$\cdot / \cdot \cdot 1$ & IVG & 1 & II/GAF & $\cdot / \cdot \Delta \cdot$ & - ITED &.$/ 490$ & برونَرايى، روانرنجورخويى و الكوى همنوايى & $r$ \\
\hline
\end{tabular}

جدول r. ضرايب استاندارد و غيراستاندارد در معادله ركرسيون با مدل كام به گام

\begin{tabular}{|c|c|c|c|c|c|}
\hline \multirow{2}{*}{$\mathbf{T}$} & \multicolumn{3}{|c|}{ ضرايب ركر سيون } & \multirow{2}{*}{ متغير بيشبين } & \multirow{2}{*}{ 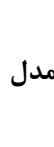 } \\
\hline & B ا ندارد شده & انحراف معيار & Bير استاندارد B & & \\
\hline$* * \Delta / T \wedge F$ & 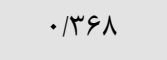 & .1 .91 & . MTY & برون كرايى & 1 \\
\hline$* * \Delta / 119$ & - MFG & $\cdot 1 \cdot 9$ & $\cdot \pi \cdot \Delta$ & برون گرايى & \\
\hline$* *-r|\varphi| 1$ & $-\cdot / T F Q$ & $.1 \cdot 9$. & $-\cdot / T I V$ & روانرنجور خويى & 1 \\
\hline$* * F / 19 r$ & - /TAF & $.1 \cdot 4$. & $\cdot / T \Delta \cdot$ & برون & \\
\hline$* *-r / G F \lambda$ & $-\cdot / T T F$ & .1 .84 & $-\cdot / Y \wedge \Lambda$ & روانرنجور خويى & $r$ \\
\hline$*-r / 4 \mid \Lambda$ & $-\cdot /$ TFF & $.1 .9 \mathrm{~V}$ & $-\cdot / \pi \mu$. & الكوى همنوايى & \\
\hline
\end{tabular}

$* * \mathrm{P} \leq \cdot 1 \cdot \cdots 1 \quad * \mathrm{P} \leq \cdot 1 \cdot \cdot 1$ 
بيشتر تجربه كنند، نخست وضعيت سلامتى خود را پايينتر ارزيابى مى كنند كه اين امر خود باعث كاهش كيفيت زندكى مىشود. در تبيين رابطه مثبت برون كرايى و ساز كارى با كيفيت زندگى مىتوان كفت افراد برونگرا و ساز كار وقايع زندكى مثبت را بيشتر تجربه مىكنند و جنين تجربهاى احساس رضايت بيشتر را در آنان ايجاد مى كند كه اين امر باعث افزايش كيفيت

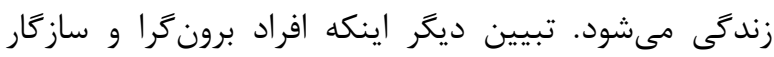
دوستان بيشترى دارند و اكثر اوقات خود را در جمع دوستان سيرى كرده و انكيزه بيشترى براى برقرارى روابط صميمانه با دان

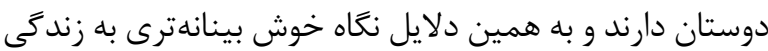
دارند و به طور كلى وضعيت سلامتى خود را مثبتتر ارزيابى مى كنند كه اين امر باعث افزايش كيفيت زندكى آنان مىشود. در تبيين رابطه مثبت يذيرش با كيفيت زندگى مىتوان كفت كه ميان يذيرش با خلاقيت و تفكر واكرا رابطه مثبتى وجود دارد و اين امر باعث مىشود كه افرادى داراى ويزگگ يذيرش از سوى ديخران تاييد شوند، راحتتر به موقعيتهاى بالاتر دست يابند و خودشان احساس رضايت بيشترى از زندكى شغلى نائى و

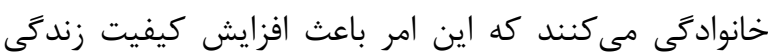
مىشود. در تبيين رابطه مثبت وظيفهشناسى با كيفيت زندكى آنى مىتوان كفت كه افراد وظيفهشناس تمايل زيادى براى اتمام كار خود به نحو احسن دارند و اين امر باعث افزايش شانس آنان براى دريافت پاداش و تاييد مىشود. اين امر در درجه نخست باعث افزايش احساس احترام و كمال و در نهايت باعث افزايش كيفيت زندگى مىشود [TV]. يافتهاى ديكر اين يزوهش نشان

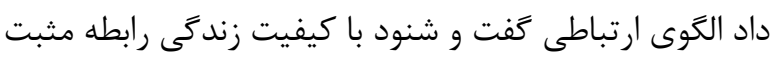
و معنادار و الكَوى ارتباطى همنوايى با كيفيت زندگى رابطه

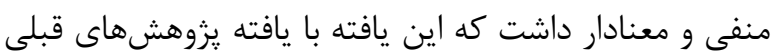
در اين زمينه همسو بود [91 -9 19]. براى مثال Zarei و همكاران

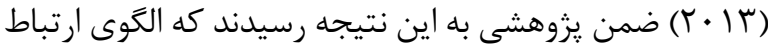
كفت و شنود با تابآورى و كيفيت زندكى رابطه مستقيم و معنادار و الكَى ارتباطى همنوايى با تابآورى و كيفيت زندكى رابطه معكوس و معنادار داشت [91]]. همجنين شهركىثانوى و

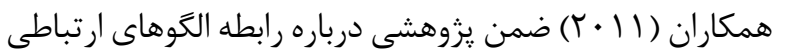
خانواده و كيفيت زندكى به اين نتيجه رسيدند كه الكوى
جدول ץ نتايج ضرايب استاندارد و غير استاندارد متغيرهاى وارد شده در معادله رگرسيون با مدل گامبه گام براى ييشبينى موثرترين متغيرها در بيشبينى كيفيت زندگى ارائه شده است. وارد شده در معادله ركرسيون با مدل كامبه گام براى ييشبينى موثرترين متغيرها در ييشبينى كيفيت زندگى ارائه شده است. بر اساس يافتههاى جدول گ و با قبول ترتيب ورود متغيرها در

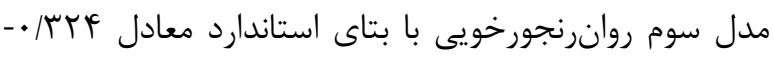
بيشترين سهم را در بِيشبينى تغييرات كيفيت زندكى

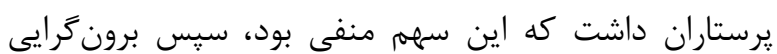

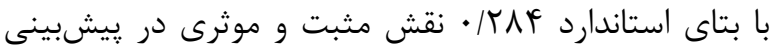
تغييرات كيفيت زندگى :رستاران داشت و در نهايت الكَى

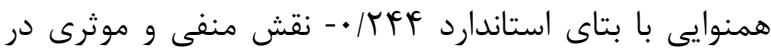
يِيشبينى كيفيت زندگى يرستاران داشت.

يافتههاى اين يزوهش نشان داد روانرنجورخويى با كيفيت

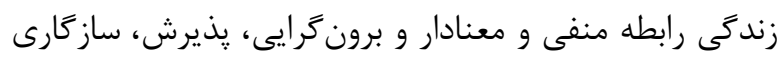

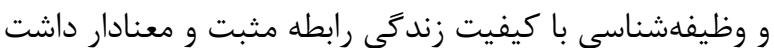
كه اين يافته با يافته يزوهشهاى قبلى در اين زمينه همسو بود

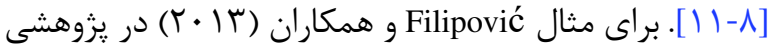
به اين نتيجه رسيدند كه بين اضطراب و روانرنجورخويى با كيفيت زندگى رابطه معنادار منفى و بين برونگرايى، يذيرش، سازكارى و وظيفهشناسى با كيفيت زندگى رابطه معنادار مثبت وجود داشت [9]. همجنين حميد و زمستانى (T/ • ץ) ضمن يزوهشى با عنوان رابطه هوش معنوى و ويزگى هاى شخصيتى با كيفيت زندگى در دانشجويان يزشكى به اين نتيجه رسيدند كه روانرنجورخويى با كيفيت زندكى رابطه منفى و معنادار و برونكرايى، يذيرش، سازكارى و وظيفهشناسى با كيفيت زندگى رابطه مثبت و معنادار داشتند [11]. در تبيين رابطه منفى روانرنجورخويى با كيفيت زندگى مىتوان كفت افراد روانرنجورخو نسبت به ساير افراد وقايع زندگى منفى را بيشتر تجربه مى كنند و علاوه بر آن وقايع را منفى تر ارزيابى مى كنند،

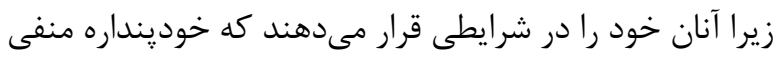
خود را تقويت كنند. هر جه افراد روانرنجورخو اين شرايط را ران 
در اين يزوهش مهمترين محدوديت استفاده از روش همبستخى و ابزارهاى خودگزارشدهى بود. در اين روش روابط كشف شده را نمىتوان به عنوان روابط على فرض كرد و در ابزارهاى خودَزارشدهى ممكن است افراد خويشتننگرى كافى نداشته باشند و مسئولانه به گويهها ياسخ ندهند. محدوديت ديگر اين يزوهش مشكلاتى در زمان اجرا بود كه تلاش شد با بيان هدف يزوهش و دريافت موافقت رئيس بيمارستانها ين مشكل را برطرف كرد. محدود شدن نمونه يزوهش به يرستاران بيمارستانهاى شهر ورامين محدوديت ديخر بود. ييشنهاد مىشود در يزوهشهاى آتى براى جمعآورى داده از مصاحبههاى ساختار يافته و نيمه ساختار يافته استفاده شود. همجنين انجام يزوهشهاى مداخلهاى براى بررسى تاثير آنها و دستيابى به رابطه على نيز ييشنهاد مناسبى براى انجام يروهش در آينده مىباشد. علاوه بر آن يزوهش بر روى يرستاران ساير شهرها مىتواند زمينه جديدى براى مطالعه باشد. به هر حال به نظر مىرسد درباره كيفيت زندگى به ويزه كيفيت زندگى يرستاران بايد يثوهشهاى بيشترى انجام شود.

\section{نتيجه كيرى}

نتايج اين يزوهش نشان داد كه متغيرهاى روانرنجورخويى و الكوى ارتباطى همنوايى با كيفيت زندگى :رستاران رابطه منفى و معنادار و متغيرهاى برون گرايى، يذيرش، سازگًارى، وظيفهشناسى و الكَى ارتباطى گَفت و شنود با كيفيت زندگى يرستاران رابطه مثبت و معنادار داشتند. همجنين در يك

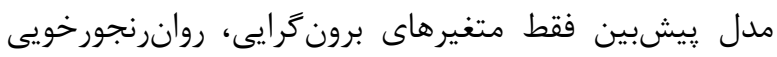
و الگوى ارتباطى همنوايى توانايى ريشبينى كيفيت زندگى ميى يرستاران را داشتند كه سلهم روانرنجورخويى در ييشبينى كيفيت زندگى يرستاران بيش از ساير متغيرها بود. بنابراين درمانگران، مشاوران و روانشناسان بالينى براى افزايش كيفيت زندگى نخست بايد به افراد آموزشهايى براى دور شدن از روانرنجورخويى دهند، سيس به آموزش برون گرايى بيردازند و در نهايت به افراد آموزشهايى براى رهايى از الكوى ارتباطى همنوايى دهند. همجنين برنامهريزان و مسئولان بيمارستانها براى افزايش كيفيت زندگى زيرستاران بايد به نشانهاى
ارتباطى گفت و شنود با كيفيت زندگى رابطه مثبت و معنادار و الخوى ارتباطى همنوايى با كيفيت زندگى رابطه منفى و معنادار داشت [9 1 ]. در تبيين اين يافته مىتوان كَفت افراد داراى الكوى ارتباطى همنوايى برخلاف افرادى داراى الگوى ارتباطى كفت و شنود كه آزادانه ابراز وجود كردند به دليل اينكه دائما به آنها امر و نهى و تاكيد بر اطاعت و همنوايى شده، خود كارآمدى و عزت نفس وايينترى دارند و نمىتوانند به راحتى ابراز وجود كنند.

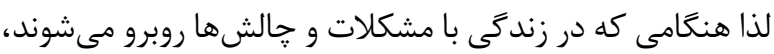
نمى توانند با استفاده از راهبردهاى مثبت و سازگًار با آنها مقابله كنند و به همين دليل كيفيت زندگى گايينترى دارند كه در نتيجه الكوى همنوايى باعث كاهش كيفيت زندگى و الكوى كفت و شنود باعث افزايش كيفيت زندكى مى شود. تبيين ديگر اينكه افراد در خانوادههاى داراى الكوى ارتباطى گفت و شنود برخلاف افراد در خانوادههاى داراى الغوى ارتباطى همنوايى قادر هستند تا نيازها، خواستهها و علاقههاى خود را با اعضاى خانواده در ميان بحذارند، عشق، دوستى و محبت را نسبت به يكديگر ابراز كنند و به خوبى از عهده مشكلات و مسائل برآ يند كه اين امر نخست باعث افزايش عزت نفس و خوينداره مثبت و بهبود مهارتهاى اجتماعى و در نهايت باعث افزايش كيفيت

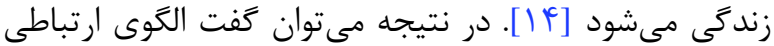
كفت و شنود با تاثيراتى كه دارد باعث افزايش كيفيت زندگى و الگوى ارتباطى همنوايى با تاثيراتى كه دارد باعث كاهش كيفيت زندگى مىشود. نتايج ديخر اين يثروهش نشان داد در يك مدلى كه صفات شخصيت (روانرنجورخويى، برونزرايى، يذيرش، سازگارى و وظيفهشناسى) و الكوهاى ارتباطى خانواده (الكوى كفت و شنود و الكوى همنوايى) براى پيشبينى كيفيت زندگى زيرستاران رقابت نمايند، متغيرهاى برونَرايى، روانرنجورخويى و الكوى ارتباطى همنوايى توانايى ييشبينى معنادار كيفيت زندگى :رستاران را داشتند كه با توجه به بتاى استاندارد روانرنجورخويى بيشترين سهم را در ييشبينى كيفيت زندگى يرستاران داشت كه اين سهمم منفى بود. پِس آنجه در يِيشبينى كيفيت زندگى نقش عمده اى ايفا مى كند در درجه نخست اين است كه افراد خود را روانرنجورخو ارزيابى نكنند. 


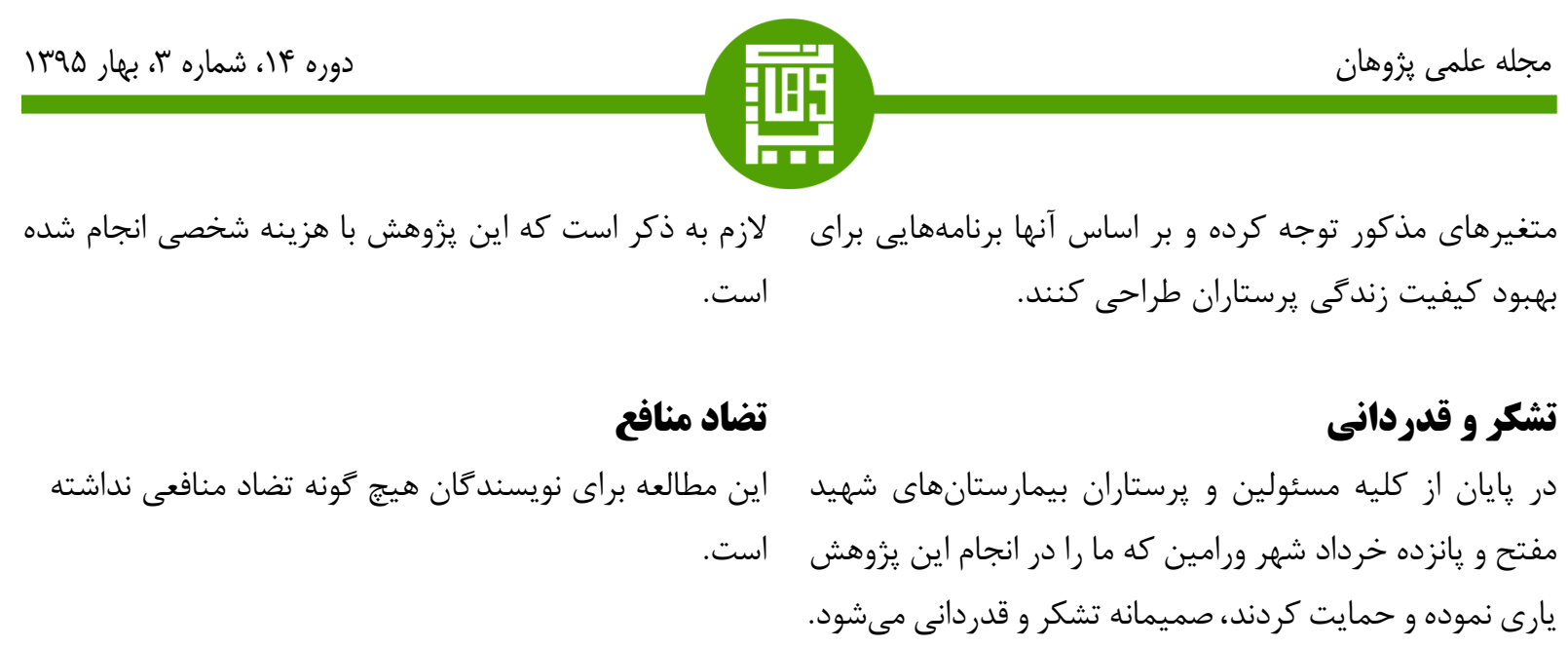

\section{References}

1. Soltan Ahmadi F. The relationship between perceived social support and psychological hardiness with life satisfaction among nurses of Mashhad hospitals [MA Dissertation]. Mashhad:Islamic Azad University of Neyshabur Branch;2015. (Persian)

2. Pour S. Exploring psychological stressors with regard to the moderating role of perceived social support in female nurses of hospital emergency department. Iran Occupational Health. 2013;10(4):65-74. (Persian)

3. Cepeda-Valery B, Cheong AP, Lee A, Yan BP. Measuring health related quality of life in coronary heart disease: The importance of feeling well. International Journal of Cardiology. 2011;149(2):4-9.

4. World Health Organization. The world health organization quality of life (WHOQOL)-BREF. Geneva:World Health Organization;2004.

5. De Haro JM, Castejon JL, Gilar R. General mental ability as moderator of personality traits as predictors of early career success. Journal of Vocational Behavior. 2013; 83(2):171-180.

6. Spotts EL, Lichtenstein P, Pedersen N, Neiderhiser JM, Hansson $\mathrm{K}$, et al. Personality and marital satisfaction: a behavioral analysis. European Journal of Personality. 2005;19(3):205-227.

7. Costa PR, Terracciano A, McCrae RR. Gender

differences in personality traits across cultures: Robust and surprising findings. Journal of Personality and Social Psychology. 2001;81(2):322-331.

8. Takeshita H, Ikebe K, Kagawa R, Okada T, Gondo Y, et al. Association of personality traits with oral healthrelated quality of life independently of objective oral health status: A study of community-dwelling elderly Japanese. Journal of Dentistry. 2015;43(3):342-349.

9. Filipović BF, Randjelovic T, Ille T, Markovic O, Milovanović B, et al. Anxiety, personality traits and quality of life in functional dyspepsia-suffering patients. European Journal of Internal Medicine. 2013;24(1):8386.

10. Sheykholeslami A, Azarniyoor S, Mohammadi N. Prediction of quality of life based on sexual attitude and knowledge, and personality traits in married women. Journal of Health and Care. 2015;17(3):260-269. (Persian)

11. Hamid N, Zemestani M. The relationship between spiritual intelligence, personality traits and quality of life in medical students. Hormozgan Medical Journal. 2013;17(4):347-355. (Persian)

12. Sigelman CK, Rider EI. Life-span human development 7th Ed. Belmont, CA:Wadsworth;2012.

13. Baxter LA, Bylund CL, Imes RS, Scheive DM. Family communication environments and rule-based 


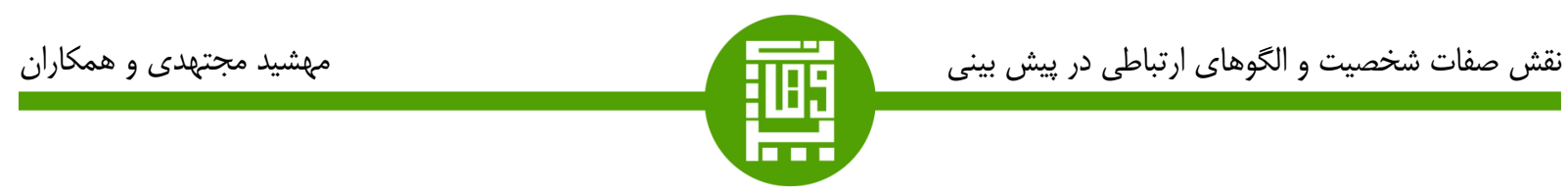

social control of adolescents' healthy lifestyle choices. 2014. Pajouhan Scientific Journal. 2015;13(4):51-59. Journal of Family Communication. 2005;5(3):209-227. (Persian)

14. Koerner AF, Fitzpatrick MA. Toward a theory of family communication. Communication Theory. 2002;12(1):70-91.

15. Fitzpatrick MA. The family communication patterns theory observations on its development and application. Journal of Family Communication. 2004;4(3-4):167179.

16. Zarei E, Fallahchai SR, Vahedi Sarrigani N. The study of relationship between family communications patterns with resilience and quality of life the high school girl's students. Journal of Life Science. 2013;3(4):289-293.

17. Sanavi FS, Baghbanian A, Shovey MF, AnsariMoghaddam A. A study on family communication pattern and parenting styles with quality of life in adolescent. Journal of Pakistan Medical Association. 2013;63(11):1393-1398.

18. Asgari S, Rashidi A R, Naghshineh T, Sharifi S. The relationship between Family communication patterns and differentiation of self with quality of life of women applicant divorce. Frooyesh. 2015;4(2):87-112. (Persian)

19. Shahraki Sanavi F, Navidian A, Ansari Moghaddam AR, Faraji Shoy M. Investigation the relationship of family communication patterns in quality of life among adolescents. Journal of Family Counselor Psychiatry. 2011;1(1):101-114. (Persian)

20. Alipoor R, Ebrahimi A, Omidi R, Hedayati A, Ranjbar H, Hosseinpour S. Depression, anxiety, stress and related demographic variables in nurses of Valiasr hospital in Fasa university of medical sciences in
21. Kozako AMF, Safin SZ, Abdul Rahim AR. The relationship of big five personality traits on counterproductive work behavior among hotel employees: An exploratory study. Journal of Procedia Economics and Finance. 2013;7:181-187.

22. Shokri O, Daneshvar Pour Z, Askari A. Gender differences in academic performance: The role of personality traits. Journal of Behavioral Sciences. 2008;2(2):127-142. (Persian)

23. Koroshnia M, Mazidi M, Hosienchari M. Relation between perceived communication patterns in family and religiosity among university students. Journal of New Education Thought. 2010;6(3):45-66. (Persian)

24. Yazdi-Ravandi S, Taslimi Z, Jamshidian N, Saberi H, Shams J, Haghparast A. Prediction of quality of life by self-efficacy, pain intensity and pain duration in patient with pain disorders. Basic and clinical neuroscience. 2013;4(2):11-18.

25. Yazdi-Ravandi S, Taslimi Z, Saberi H, Shams J, Osanlo S, Nori G, et al. The Role of Resilience and Age on Quality of life in Patients with Pain Disorders. Basic and clinical neuroscience. 2013;4(1):24-30.

26. Masaeli N, Attari A, Molavi H, Najafi M, Siavash M. Normative data and psychometric properties of the quality of life questionnaire for patients with diabetes mellitus. Koomesh. 2010;11(4):263-269. (Persian)

27. Najjar A. Relation between psychological hardiness, personality traits and perceived organizational support with mental health and quality of life [MA Dissertation]. Semnan:Islamic Azad University of Garmsar Branch;2016. (Persian) 


\title{
The role of personality traits and family communication patterns in prediction of qualityof life among nurses of Shahid Mofatteh and 15 Khordad hospitals in Varamin city, 2015
}

\author{
Mahshid Mojtahedi ${ }^{1}$, Jamal Ashoori ${ }^{2 *}$ \\ 1. MA of Educational Administration, Department of Educational Science, Urmia University, Urmia, Iran \\ 2. Ph.D. of Psychology, Department of Psychology, Isfahan (Khorasgan) Branch, Islamic Azad University, Isfahan, Iran
}

\section{(1) fliels Info}

Recieved: 16 Mar. 2016

Accepted: 30 May 2016

\section{Key w ords}

Personality traits

Family communication patterns

Quality of life

Nurses

\section{Oorerponding huthor}

Jamal Ashoori, Ph.D. of Psychology, Department of Psychology, Isfahan (Khorasgan) Branch, Islamic Azad University, Isfahan, Iran

Tel: +982136729688

Email: Jamal_ashoori@Yahoo.com

\section{Oitation}

Mojtahedi M, Ashoori J. [The role of personality traits and family communication patterns in prediction of qualityof life among nurses of Mofatteh and 15 Khordad hospitals in 2015] Pajouhan Scientific Journal. 2016;14(3):20-29

\section{(1) bs s a e 1}

Introduction: Quality of life is affected by several psychological factors of which personality traits and family communication patterns can be noted as the most important ones. This research aimed to investigate the role of personality traits and family communication patterns in prediction of quality of life among nurses.

Methods: This is a descriptive-analytical study of cross-sectional type. The statistical population included 180 nurses of Shahid Mofatteh and 15 Khordad hospitals of Varamin city in 2015 , as selected by stratified randomly sampling method. The data was collected through questionnaires comprising personality traits of Costa \& McCrae, family communication patterns of Koerner \& Fitzpatrick and quality of life of World Health Organization. Data was analyzed by Pearson correlation and multivariate regression with using SPSS-19 software. Results: The results showed that neuroticism and conformity communication pattern had a significantly negative relationship with quality of life of nurses; and extroversion, openness, agreeableness, conscientiousness and conversation communication pattern had a significantly positive relationship with life quality of nurses $(\mathrm{P}<0.05)$. In the other hand, extroversion, neuroticism and conversation communication pattern predicted 24.5 percent of life quality variance of nurses $(\mathrm{P}<0.001)$. Also, the share of neuroticism in predicting quality of life was more than other variables $(\mathrm{P}<0.001)$.

Conclusion: Extroversion, neuroticism and conversation communication pattern reveal a significant ability of predicting quality of life among nurses. Therefore, these variables can have an effective role in improving the quality of life of nurses. It is suggested that therapists should consider these variables and design appropriate programs, based on them, to improve the quality of life of nurses.

(C) 2016 Pajouhan Scientific Journal. All right reserved 